УДК 638.178.2

\title{
ОБГРУНТУВАННЯ ВИКОРИСТАННЯ ЛІСОВОГО МЕДОЗБОРУ У ФОРМУВАННІ ІМУНІТЕТУ БДЖІЛ
}

\author{
Вербельчук Тетяна Василівна \\ кандидат сільськогосподарських наук, доцент \\ Поліський національний університет \\ ORCID: 0000-0001-7334-4507 \\ Email: ver-ba555@ukr.net \\ П'ясківський Володимир Марцинович \\ кандидат сільськогосподарських наук, доцент \\ Поліський національний університет \\ ORCID: 0000-0001-6382-3328 \\ Email: Payskovskiy_VM@ukr.net \\ Вербельчук Сергій Петрович \\ кандидат сільськогосподарських наук, доцент \\ Поліський національний університет \\ ORCID: 0000-0002-1136-5617 \\ Email: verba5551@ukr.net
}

Гавриловський Володимир Петрович викладач, заступник директора з навчально-виробничої роботи Житомирський агротехнічний коледж ORCID: 0000-0001-5767-6093 Email: gavrilovskiy50@gmail.com

Еволюційний розвиток бджіл проходив на багатій поліфлорній кормовій базі. Бджола медоносна відноситься до комах з вузькоспеціалізованим живленням. Весь комплекс поживних речовин необхідних для розвитку та харчування потомства і імаго отримується з нектару та пилку, які бджоли, для тривалого зберігання, консервують в мед та пергу. Кормова цінність квіткового пилку визначається вмістом в ньому білку, повноцінністю амінокислотного складу, здатністю до засвоєння. Вибірковість збирання пилку частково пояснюється потребою бджіл на даний період у тих чи інших речовинах. Крім того встановлено, що пилок різних пилконосів відрізняється своєю біологічною цінністю, пилковою продуктивністю, хімічним складом. Доведено, що однією з причин зниження імунітету бджіл є погіршення їх живлення. Це викликано зменшенням біорізноманіття квітуючих рослин біля полів, монокультурним землеробством, високим пестицидним фоном, змінами клімату тощо. Тому, поліфрлорна повноцінна пилково-нектарна кормова база відіграє основоположну роль для життя та розвитку бджіл. Повноцінне вигодовування личинок закладає на все подальще життя комах базу імунної стійкості, здоров'я, тривалості життя. Надто важливим це є для відтворення майбутніх маток, трутнів. Відомо, що в стадію личинки йде формування так званого жирового тіла, котре є депо білків та інших БАР, а в подальшому виступає основою формування секреторної діяльності (маточного молочка, ферментів для переробки нектару, восковиділення тощо). Формування жирового тіла проходить в період личинкової стадії розвитку розплоду. Воно забезпечує тривале життя зимуючих бджіл, здатність вижити та пережити холоди, сприяє виконанню надважливого завдання цих бджіл вигодовування однієї бджоли заміни тощо. Літні короткоживучі бджоли вигодовують до чотирьох особин. Як і у вищих тварин та людини в підтриманні імунітету важливу роль відіграє мікрофрлора слизових і кишківника. Вона частково забезпечує ферментативні процеси в травленні. Завдяки цим сапрофрітним мікроорганізмам - формується імунітет (до 80 \%). Ліс здатен забезпечити бджіл ранніми поліфрлорними квітуючими рослинами, що поліпшить повноцінність білкового живлення, сприятиме високій життєздатності потомства та активному нарощуванні сили сім'ї, майбутній продуктивності, зимостійкості, забезпечить ефективність галузі.

Ключові слова: бджола, монокультурне землеробство, харчові стреси бджіл, нарощування сили сімей, медоноси лісу, імунітет.

DOI: https://doi.org/10.32845/bsnau.Ivst.2021.2.10

В 2020 році медозбори Європейського комерційного бджільництва скоротились на 40 \%, а деякі країни виробили його лише $10 \%$ до сталих років [3, 29].

Основними причинами називаються харчові стреси бджіл, несприятливі кліматичні умови, скорочення термінів квітування медоносів, вплив використання монокультурного рослинництва тощо [16, 20, 26, 31].

Медоносні бджоли є комахами з вузькоспеціалізованим живленням, їх тривале і еволюційне становлення про-

ходило на багатій поліфрлорній базі $[12,20]$. Всі поживні речовини (білки, вуглеводи, жири, мінеральні речовини, вітаміни, частково вода) необхідні для розплоду та імаго, отримують з нектару та квіткового пилку, котрі, для тривалого зберігання, переробляються на мед та пергу [2, 9, 18, 26].

Гідроліз корму до складових проходить під впливом специфічних ферментів та ферментів сапрофітних мікроорганізмів кишківника. Визначальний вплив на сформований імунітет бджіл спричиняє мікрофлора. На ї̈ формування

Вісник Сумського національного аграрного університету 
впливає ряд фракторів: якість корму, стан організму, вплив отрут і т. д. [8, 12, 19, 23, 26].

Сучасне інтенсивне землеробство різко змінило якість та доступність кормової бази бджіл, призвело до монокультурності, порушення сівозмін, високого рівня добрив та пестицидів, ГМО [5, 7, 10, 16, 18, 20, 26].

Кліматичні зміни призводять до порушення тривалості та послідовності квітування медоносів, скорочення нектаровиділення та ін. [26].

Експерти однією з причин зниження імунітету та загибелі (колапс бджолиних сімей CCD) називають звуження кормової бази, дія різних токсичних факторів, зменшення корисних мікроорганізмів в травному тракті комах та інші [7, $10,15,20,30]$.

Харчового стресу можна уникати шляхом ширшого залучення в якості джерел корму природного біорізноманіття флори, особливо лісової.

Бджолосім'я, особливо у ранньовесняний період, коли інтенсивно проходить зміна поколінь, скорочуються ресурси зимувалих бджіл, потреби у надходженні білкового та вуглеводного корму $€$ надто важливою $[12,18,23]$.

У весняний період створюються передумови сильних сімей, якісного запилення ентомофільних рослин, високих медозборів, успішної майбутньої зимівлі [21, 22].

Кормова цінність пилку визначається за вмістом та якістю білку, здатністю до перетравлювання та його засвоєння як білково-вітамінно-мінерального корму [2, 6, 26, 30, 31].

За поживністю для вигодовування розплоду пилок прийнято поділяти на три класи: дуже поживний що забезпечує найбільшу тривалість життя бджоли; менш поживний; малопоживний (збирається бджолами рідко). Пилок вітрозапильних рослин має нижчу поживну цінність [5, 21, 33].

Мета даного дослідження та актуальність вмотивована в обґрунтуванні технології використання лісових медоносів для забезпечення якісним поліфлорним білкововітамінним кормом весняний розвиток бджолосімей, формування їх імунітету та продуктивних якостей.

Обґрунтовано заходи в боротьбі з харчовими стресами, монокультурним землеробством, пестицидним навантаженням шляхом застосовування лісових деревних, кущових й трав'янистих квітуючої рослинності. Цей прийом сприяє підвищенню імунітету всіх особин бджолиної сімці, їх життєздатності, продуктивності, зимостійкості та ефективність галузі в цілому.

Матеріали та методи досліджень. При проведенні досліджень застосовували загальнонауковий метод - системний аналіз, котрий передбачає оцінку системи у взаємозв'язку з факторами, що випливають з нього. Метод досліджень заключається у системному співставленні, узагальненні явищ та зав'язків, при абстрактно-логічному формуванні висновків.

Результати досліджень. В 2020 р Україна виробила біля 80 тис. т меду, що є першим місцем в Європі та складає $4 \%$ світового виробництва [2, 29].

Активне весняне наростання сили сімей відбувається з періоду квітування в природних пилконосних та медоносних рослин. Свіжий пилок сім'я починає збирати з перших весняних вильотів [2, 9, 12, 20, 22, 33].

Джерелом для бджіл білків, жирів, вітамінів та мінеральних речовин $є$ пилок квіткових рослин [2, 12, 18, 24].
Тривалість життя бджолиних особин прямо залежить від спожитої білкової їжі та вирощуваного розплоду [12, 18, 23].

Дорослі бджоли восени та взимку можуть тривалий час існувати на одному меді. Проте на період коли в сім'ї $\epsilon$ розплід, потреба в білковому кормі різко зростає, так як бджоли частково годують личинок кашкою, приготовленою 3 меду, пилку та води [12].

Молоді бджоли весняних генерацій вкрай потребують білкового живлення. При відсутності пилку глоткові залози у них не розвиваються та не продукують речовини, що входять до складу маточного молочка, а воскові залози не виділяють віск [12, 18, 24, 27].

В біології бджолиної сім'ї надто важливо повноцінно вигодувати перші два весняні покоління бджіл. Це можуть зробити тільки старі, та фізіологічно розвинені, стійкі бджоли, котрі мають суттєвий запас білку в жировому тілі. Зимувала бджола є суттєво, спрацьованою під дією стресових екстремальних умов зимівлі.

Біологічна особливість бджіл та інших комах полягає в тому, що інтенсивне формування жирового тіла, своєрідного депо білків, жирів та інших необхідних речовин проходить лише в стадію розвитку личинки, а витрачається на подальший розвиток органів у розплоду та життя імаго [12, 22, 33].

Весь простір під зовнішнім покровом личинки та між органами заповнюється розвинутим жировим тілом. Воно сягає 60-65 \% маси личинки та витрачається частково в стадії передлялечки і лялечки на формування органів, покровів і для подальшого онтогенезу комахи [12].

Від збереження стану жирового тіла зимуючих бджіл залежить їх здатність виробити маточне молочко для вигодовування першого, після зими покоління бджіл.

Маточне молочко годувальниць (вік 6-12 днів) в перші дві доби дуже багате на білки, до 78 \% в сухій речовині. Потім частка білку знижується, при зростанні вуглеводів та жирів [12, 23]. 3 третього дня личинки бджоли починають годувати кашкою - сумішшю перги, меду та води, яку згодовують прямо до рота.

Розвивається личинка на таких кормах дуже інтенсивно. Так, за шість днів стадії личинки маса майбутньої робочої бджоли зростає в 1500 разів [12, 18, 24].

Тобто, доросла бджола майже не здатна накопичувати жирове тіло. 3 віком у неї перебудовується і вся ферментативна система. Протеазна активність молодих бджіл годувальниць (для розщеплення білків) деградує, і змінюється на інвертазну діяльність по розщепленню цукрози, необхідної для переробки нектару в мед. Тобто, лише фізіологічно зрілі молоді бджоли здатні перетравлювати білок та виробляти маточне молочко. У дорослих особин це частково проходить під дією корисної мікрофлори кишківнику.

Таким чином свіжі пилок та перга необхідні в першу чергу для розвитку весняним бджолам вже другого та подальших поколінь. Це приходиться, для першого покоління на час, як правило, приблизно на початок березня, а самі стати годувальницями другого покоління вони зможуть в кінці березня. В цей час в природі вже з'являється широкий спектр пилконосів, білкового корму.

Завдання зимувальної бджоли пережити зиму та вигодувати одну бджолу заміни, в т. ч. коли літні бджоли вирощені за кращих харчових умов вигодовують чотири бджо- 
ли $[18,23]$.

Роль лісу для бджіл, як лісової комахи надзвичайна. Це джерело кормів та життя. Широкий спектр медоносів лісу представлений ярусами деревних культур, кущової та трав'янистої рослинності, здатні підтримати життєдіяльність сім'ї, їх розвиток [5, 4, 18, 16, 20, 21].

В природі переважають ентомофрільні рослини (майже 80 \%). У вітрозапильних рослин пилок дуже дрібний та сипучий, його утворюється значно більше (їх - біля $20 \%$ кукурудза, береза, дуб, ліщина, ряд злакових та ін.). Деякі з повітрязапильних рослин можуть запилюватись як вітром, так і комахами (верба, дуб, виноград, ревінь) [18, 21].

За теплої погоди та доброго освітлення сонцем рослини повне нектаровиділення відбувається лише за умов достатньої вологості повітря (60-80 \%) та ґрунту. Ліс протидіє, подовжує, згладжує суховії та температурні перепади. Особливо несприятливими для виділення нектару $є$ вітри. Це холодні північні та північно-східні та південні суховії на весні $[18,23]$.

Медопродуктивний запас лісів суттєво коливається у в залежності від ряду факторів. Вищою медпродуктивністю виділяються ліси в яких переважають листяні породи та є хороший кущовий підлісок [5].

За даними, медоносна фрлора України нараховує близько 900 видів котрі бджоли використовують як джерело нектару. Із зазначеної кількості видів - близько 472 - основні медоноси. Вони належать до 74 родин, з яких п'ять представлені найбільшою кількістю видів. За аналізом життєвих форм основна частина медоносів представлена трав'янистими рослинами, - 70,2 \%, дерева складають 16,1, кущі - 10,7, напівкущі та ліани - 3 \% [5, 16. 18, 23].

Дикоростучі медоноси є комплементами екосистем луків, лісу чи болота, - і від цього, великою мірою, залежить нектаропродуктивність зазначених угідь.

Збереження та поліпшення біорізноманіття середовища $€$ важливою умовою перспектив сталого розвитку бджільництва, збереження бджоли медоносної та інших диких запилювачів [8, 20, 26, 31].

Останні десятиліття людство б'є все більшу тривогу по збереженні природного біорізноманіття. Цей пріоритет визначений як один з основоположних у збереженні життя на Землі (Конвенція ООН по захисту біологічного біорізноманіття у всіх його формах - Ріо-де-Женейро, 5.06.1992 року та підсумкове засідання до 25-річчя діяльності - Париж, 29.04.2019 рік) [31].

Медоноси лісів належать до найбільшої групи. Вони поширені по всій території Житомирщини й істотно впливають на формування нектарного балансу заліснених територій. Залежно від типу ліси різняться за своїм поширенням, медоносними властивостями та загальними запасами. Це типи угідь досить різноманітні і значно мінливі між собою за кількістю виділеного рослинами нектару. Так, якщо широколистяні ліси зі значною кількістю липи можуть бути джерелом промислового медозбору, то більшість ялинових та ялицевих лісів - лише підтримуючого. Для бджільництва найбільшу цікавість складають ліси та деревно-кущові насадження в яких є липи, клени, верби, а з кущових - малина, крушина, верес, з трав'янистих - іван-чай та інші $[5,4,18$, 23, 26].

Найбільш високі медозбори у лісові зоні мають зріджені ліси з поліфлорним травостоєм, полянами, галявинами.
В нижньому ярусі їх активно медоносить кущова та трав'яниста рослинність [5, 18].

Серед медоносних дерев переважаюче їх число належить до супутніх порід другого ярусу. Вони активно розвиваються під покровом світолюбивих крон дуба, ясеня, сосни. Це тіньовитривалі дерева, котрі добре ростуть в другому ярусі, задовольняючись сонячною енергією що надходить через крону головних порід.

Кращими для бджільництва є лісові масиви, де головні породи складають 70-80 \%, а супутні другого ярусу - 2030 \%. Бажаними тут є липи, клени, явір, акація біла, верби, груша, гледичія, яблуня, алича, абрикос тощо [18, 23].

Кращими прибережними медоносами водойм $€$ верби (п'ятичинкова, прутоподібна, пурпурова, чорніюча та ін.). На прирічкових пісках продуктивними $€$ шелюга жовта та червона, верби.

В дослідах виявлено, що з принесеного обніжжя, 15 \% було з дерев та кущів сімейства розоцвітних, $11 \%-3$ берези, в'яза, бука, дуба, 54 \% з конюшини, решта - 3 інших трав'янистих рослин $[21,23]$.

Значну медопродуктивну цінність на перспективу можуть складати вирубки та згарища. Зазвичай 3 другого року площі починає займати іван-чай. Медозбір з нього триває 5-6 років. В подальшому він витісняється малиною. Ці обидва медоноси поступово змінюються молодим деревним підліском. Зазвичай на згарищах медоноси живуть дещо довше ніж на вирубках [23].

Великі пожежі в 2020 році нанесли збитків лісам Житомирщини на суму понад 1 млрд гривень [25].

На півночі Житомирщини розташовано також ряд заповідних територій. Це Поліський заповідник (20104 га), ряд заказників, зони відчуження та ін. Їх лісові угіддя можуть 3 успіхом використовуватись в органічному виробництві.

Пилок для бджіл є основним джерелом білку, жиру, мінеральних солей, вітамінів та інших речовин, котрих мало, або вони зовсім відсутні у меді, і котрі необхідні для нормального живлення молодих бджіл, вирощування розплоду, виділення воску та виконання інших робіт в сім'ї [23]. Пилок різниться за хімічним складом білків: кукурудза - 4,5 \%, ліщина $-30 \%$.

Жиру з пилку берези - 1\%, кульбаб -14,4%. Кращий на корм - змішаний пилок [12]

Хімічний склад білку теж коливається в широких межах. Білкових речовин від 22 до 40\%, амінокислот - 18 \% $[18,24]$.

Пилкові зерна та нектар $є$ головним джерелом для виробництва бджолами проліну, однією з найбільших (45-80 $\%$ від всіх) амінокислот меду. Це $є$ головним показником зрілості та натуральності меду. Актуальною проблемою стає міграція важких металів в ланцюжку ґрунт-рослина-людина. Це стосується свинцю та кадмію. Проте відмічена суттєва видова вибірковість їх накопичення в рослині та регенеративних органах [35, 36].

На сучасному рівні ведення землеробства у якості ранньовесняного нектаро- та пилконосу використовують посіви озимого ріпаку, котрий квітує 25-35 днів, починаючи, як правило з початку травня [33].

Штучний відбір пилку зменшує його надходження у гнізда та сповільняє інтенсивність весняного розвитку сімей [32].

Крім як за формою, пилкові зерна різних видів рос- 
лин розрізняються і за кольором. Так, пилок фацелії синім, гречки - грязно-білий, конюшини - коричневий і т. ін. [12, 18, 23].

При відсутності пилку бджоли нездатні зберегти у своєму тілі запаси білку.

Недогодівля маточних личинок призводить до народження маток низької якості. При нестачі пилку, бджоли можуть виганяти трутнів з вулика навіть в середині літа. Недогодівля останніх призводить до нестачі сперми [2, 12, 18, 21, 24, 31].

Перга, на відмінну від пилку, стерильна, краще перетравлюється та засвоюється. За антибіотичними властивостями вона в 3 рази переважає пилок. Важливо в лісі заготовити пергу для подальшого використання сім'єю [10].

Пилок краще стимулює яйцекладку матки ніж перга. Молоді бджоли мають дуже високу потребу в білку до 7 денного віку, коли проходить процес фрормування гіпофрарингальних залоз [12, 18, 26].

В пилку знайдено до 30 вуглеводів, глобуліни, альбуміни, 45 ферментів, 32 амінокислоти, жири, насичені та ненасичені жирні кислоти, каротиноїди, вітаміни, антоціаніди, фрлавоноли, оксифлавоноли, флавонони, 17 вітамінів, ароматичні, барвні та інші речовини. Всього - близько 250 сполук та елементів [1, 2, 4, 18, 21, 23].

У більшої частини рослин пилок складається з окремих одноклітинних пилкових зерен, невидимих неозброєним оком. За зовнішнім виглядом це порошок різних кольорів та відтінків. Бджоли збирають пилкові зерна, котрі є чоловічими статевими клітинами квітів. В процесі заготівлі їх бджола формує грудочку, котра переноситься в спеціальному кошику на останній парі ніжок. Такий продукт вже називається бджолиними обніжжям. Бджолине обніжжя це пилок з тичинок рослин, зібраний бджолами, до якого вони додали нектар, секрет слинних залоз та сформували грудочки (обніжки) діаметром 2-3 мм [2, 12, 18, 23, 26].

Принесене у вулик обніжжя щільно утрамбовується в бджолині комірки та герметично закривається медовою кришечкою. Під дією ферментів доданих бджолами, мікроорганізмів кишківника там проходить консервування, переважно молочнокисле. Процес триває 14 днів, і у результаті утворюється унікальний продукт тривалого зберігання перга $[2,18]$.

Повноцінний розвиток всіх членів сім'ї відбувається лише при достатніх запасах в гнізді перги.

Рослини багатьох видів утворюють пилку значно більше потреби для запилення. Цей еволюційний прийом зародився для приманювання запилювачів.

Зміна навколишнього середовища прямо впливає на життєдіяльність медоносних бджіл. Температурні та інші зміни призводять до розсинхронізації циклів бджолиної сім'ї та природного квітування рослин. Змістились строки та терміни вегетації рослин. Високі температури скорочують тривалість нектаровиділення, період квітування. Страждає весняний розвиток бджіл через недобір та доступність корму. Останній період ряд дослідників акцентують увагу на шкідливому впливу монокультур на життєдіяльність бджіл [8, $10,12,20,26,31]$.

Швидкі кліматичні зміни порушено, адаптивна здатність рослин та бджіл.

Значних втрат несе природа по відношенню до диких запилювачів. Таким чином, забезпечення сімей у весняно- літній період $є$ однією з першочергових умов створення високопродуктивних бджолиних сімей $[5,9,16,18,20,23$, 26].

Сила сімей на весні та ефективність використання раннього медозбору прямо збільшується пропорційно запасам пилку [12]. Відсутність білкових кормів, особливо під час весняного розвитку бджолосімей, може викликати захворювання на білкову дистрофію $[12,18]$. Нестача білкової їжі в раціонах медоносних бджіл може бути однією з причин появи інвазійних та інфекційних хвороб [12, 18, 23, 31].

При наявності в сім'ї значної кількості відкритого приплоду та низькому забезпеченні бджіл пергою у бджілгодувальниць може спостерігатись розлад білкового обміну і вони передчасно зношуються. При відсутності пилку, бджоли зможуть вирощувати розплід ще 2 тижні, за рахунок резервів власного тіла [12]. Личинки, котрі отримували неповноцінну, бідну на білок їжу народжуються дрібнішими, нежиттєздатними та швидко гинуть. Весняна додаткова підгодівля з пилком у сімей сприяла збільшенню вирощування розплоду майже в 2 рази.

Пилок необхідний бджолам для утворення ферментів з переробки нектару, розвитку та успішного функціонування восковидільних залоз [12].

Зимостійкість бджіл тісно пов'язана з масою тіла робочих бджіл, стану їх внутрішніх органів (жирового тіла, гіпофарингальних залоз, яєчників), кількості резервних речовин в тілі восени та вмісту води в організмі, активності каталази ректальних залоз та ряду інших ферментів [12, 18, 23].

Травний сік середньої кишки бджоли містить всі фе-рменти необхідні для перетравлення складних складових їжі. Під їх дією їжа розщеплюється до розчинних у воді речовин, котрі здатні проникати через стінки в середину клітин.

Пилкові зерна перетравлюються в середній кишці за 1-7 діб.

В організмі бджіл корми піддаються гідролізу. Це проходить під дією власних специфічних ферментів та ферментів мікрофолори кишківника. Доведено, що окрім ферментів середньої кишки, які розщеплюють органічні речовини корму, активну роль в травленні приймають ферменти, що їх продукує мікрофолора кишківника $[11,12]$. На кількість та стан мікрофрлори впливає ряд факторів. Визначальними 3 яких $€$ стан організму, вплив пестицидів, важких металів, мікотоксинів тощо $[6,8,10,15,28,35,36]$.

За поживністю для вигодовування личинок пилок поділяється на три класи. До першого (дуже поживний, забезпечує найбільшу тривалість життя) у верби, груші, конюшини, верес тощо. До другого - менш поживного відноситься соняшник, в'яз, тополі, кульбаба, кукурудза та ін. До третього - берези, вільхи, граб, сосна, ялина та інші. Останні малопоживні та збираються бджолами рідко [21]. Поліфлорний пилок лісу подовжує життя бджіл. Бджоли, котрим згодовували поліфлорний пилок жили довше, ніж ті що отримували його з монокультур $[12,23]$.

Виявлено вплив амінокислотного складу пилку на амінокислотний склад тіла личинки. Існує різниця в засвоюванні бджолами окремих амінокислот корму (при загальному високому рівні $[12,18,23,34]$.

Відмічено, що для різних періодів розвитку бджіл характерна різна потреба в окремих амінокислотах. Так, в період розвитку відкритого розплоду характерним є більш 
високе засвоювання з корму незамінних амінокислот [12].

Сучасні бджоли страждають від ряду факторів зміни клімату: скорочення терміну квітування медоносів, забрудненості пестицидами [19, 26, 31].

Доведено, що бджоли на посівах монокультур страждають від одноманітної їжі монокультур. Це виснажує бджіл, збіднює склад мікрофлори кишківника, котра, як свідчать останні дослідження, спричиняє суттєвий вплив на мікрофлору та продукований ними ферментативний склад, а там зароджується імунітет [6, 8, 10, 11, 19]

Важливу роль в цьому відіграють дикороси зі своїм поліфрлорним пилковим складом.

Тільки інтенсивна годівля народжених бджіл пилком сприяє подовженню тривалості їх життя, в порівнянні з тими, що споживали лише цукровий пилок [33].

Встановлено залежність між масою личинок та кількістю корму в гнізді (табл. 1).

Залежність між масою личинок та кількістю корму [12]

\begin{tabular}{|l|c|c|c|}
\hline \multicolumn{1}{|c|}{ Показник } & \multicolumn{3}{|c|}{ Значення } \\
\hline Кількість меду в гніздах бджолиних сімей, кг & 4,5 & 8,1 & 12,6 \\
\hline Маса маточного молочка в комірках 3-денних личинок, мг & 2,1 & 5,0 & 4,8 \\
\hline Маса 3-денних личинок, мг & 6,7 & 9,5 & 10,8 \\
\hline
\end{tabular}

Новими критичними викликами для бджіл є поширення токсинів - інсектицидів, пестицидів та інших хімічних небезпек до яких бджоли еволюційно не встигають розробити механізми детоксикації [2, 5, 7, 8, 10, 15, 20, 31].

Цікавими матеріалами є дані по миш'яку. Сам чистий миш'як, як нерозчинний, $є$ неотруйним. Отруйними $€$ його численні сполуки. Бджоли здатні накопичувати миш'якові отрути з забруднених територій в своїй продукції: пилку, меді, прополісі, куди він надходить від спалювання вугілля, видобування кольорових металів, шахт, виробництва пестицидів тощо [36]. Це стосується і до ряду інших важких металів.

Вже чітко досліджено шкодочинну дію на бджіл і навколишнє середовище пестицидів, особливо з ряду неонікотиноїдів. Період розпаду їх складає до 3-х років, проте і метаболіти їх теж спричиняють токсичну дію. Дія неонікотиноїдів призводить, до змін поведінкових реакцій годувальниць. Личинки рідше отримували корм, а розвиток їх подовжувався на 10 годин $[7,10,11,20,26,31]$.

Серед поширюваного по світу колапсу бджолиних сімей причинами дослідники називають десяток факторів. В цьому переліку причин відмічено, крім пестицидів, ГМО, використання антибіотиків, негативний вплив погіршення умов живлення бджіл, через зниження природного біорізноманіття, зменшення диких медоносів, поширення монокультурного рослинництва [5, 26, 35].

На склад мікрофлори гнізда та бджоли має вплив ряду факторів: географрічне розташування регіону, мікробіологічного складу корму, що споживають бджоли, різноманіття фллори в радіусі продуктивного льоту тощо $[4,5,9,11,14$, 16].

У загиблих від колапсу бджіл в травному тракті відмічено зовсім не перетравлений пилок, що свідчить про відсутність там бажаної мікрофрлори [11].

Останні дослідження показують, що у зв'язку з впровадженням інтенсивних технологій в Європі різко змінилась якість та доступність кормової бази бджіл. Це відбувається під впливом порушень від дотримання сівозмін, внесенням високих доз добрив, дією пестицидів на бур'яни тощо $[5,26$, 31].

Однією з основних причин скорочення чисельності диких запилювачів $€$ відсутність різноманіття кормової бази, що надає збалансоване і повноцінне харчування та забезпечує корисними мікроорганізмами травну систему бджоли $[7,26,31]$.
Останній період все ширше висіваються ГМОкультури. Вони призводять до збідніння природного біорізноманіття, спричиняють витіснення та відмирання природних рослин, котрі не можуть протистояти трансгенам [28].

Пилок трансгенів $€$ неперетравним для бджіл та ослаблює імунну систему, спричиняє виникнення хвороб [11, 16].

Крім окреслених кормових факторів ліс, в технології набуття бджолами сталого імунітету, сприяє поліпшенню ряду інших умов весняного нарощування та розвитку бджіл. Основні з них викладені нижче.

Перевага полягає в зменшенні забруднення організму та продуктів важкими металами, запобіганню попаданню в гнізда шкодочинного трансгенного пилку, неонікотиноїдів та пестицидів, інших хімічних засобів $[7,35,36]$.

Великі санітарні розриви зводять до мінімуму ризики перезараження пасік кліщем Varroa, рядом інших шкідників та хвороб.

Активне наростання сили сімей та повноцінне живлення сприяють активному восковиділенню, відбудові гнізда $[12,18,23,27]$.

Правильне розташування вуликів та їх орієнтація до пануючих вітрів у лісі здатне захистити сім'ї від холодних пронизливих вітрів, непогоди, що сприяє активній льотнозбиральній діяльності, нарощуванню бджіл, повноцінному обльоту молодих маток, вирощуванню якісних трутнів тощо $[18,22]$.

Повноцінне живлення в період личинкової стадії розплоду сильно впливає на формування жирового тіла бджоли, його імунітет та життєві сили, як в стадії розплоду, так і імаго [12].

В лісі суттєво знижене фрізичне забруднення навколишнього середовища (шум та вібрація, електромагнітне забруднення промислових об'єктів).

В галузі розроблено ряд методів, способів та технологічних прийомів котрі дозволяють виробляти певну кількість монофлорних, ексклюзивних, крафтових цінних медів, органічну продукцію [5, 16, 23].

Проте розміщуючи пасіку в лісі необхідно обстежити ділянки на наявність отруйних нектаро- та пилконосних рослин: чемериць, дурману рододендрону, азалії понтійської, богульника болотного, аконіту, беладони та ін. [14].

Чиста лісова атмосфера сприяє становленню та активній роботі мікрофолори кишківника, поліпшенню травлення складових корму. 
В Україні ще є багато унікальних природних куточків, які не зачепила виробнича діяльність, які здатні відігравати високу природоохоронну роль в завданні збереження біологічного різноманіття. Під ці ознаки частково попадають землі відчуження внаслідок аварії на ЧАЕС $[4,16,17]$.

\section{Висновки}

1. Роль лісу, як джерела білкового та вуглеводного корму для бджіл є вкрай важливою. Лісова зона характеризується різноманітними лісовими, лучними та болотними біоценозами. Вони відіграють важливу роль для бджільництва. Медопродуктивний запас лісів та інших угідь суттєво коливається в залежності від ряду фракторів.

2. Для повнішого використання можливостей кормової бази лісу необхідно детально знати особливості виділення нектару квітками, видовий склад медоносів, їх поширення в основних фітоценозах, розміщення угідь на території і їх медоносну цінність.

3. Інтенсивним технологіям ведення бджільництва притаманна раціональна технологія, в основі котрої лежить чіткий моніторинг стану кормової бази, сили сімей, пасіки. Застосування розроблених різноманітних методів та прийомів по підвищенню продуктивності бджолосімей пов'язане 3 біологією бджолородини.
4. Європейські експерти та вітчизняні дослідження однією з причин зниження імунітету та загибелі бджіл і інших комах називають скорочення різноманітності кормової бази, токсичні впливи на організм, зменшення в травному тракті бджіл корисних мікроорганізмів, що забезпечують їх імунітет. Ефективним тут розширення площ під органічним землеробством.

5. Технологічно пропонується використання лісу для ранньовесняного нарощування сімей з їх подальшою кочівлею. Цей прийом допомагає уникнути можливого потрапляння паді в зимові корми, як правило в цей період на лісових медоносах її немає, ще не розвинулись продуценти паді.

6. Розміщення сімей в лісі сприяє заготівлі якісного поліфлорного обніжжя та перги, в т. ч. і на зимове збирання гнізда. Ліс, та особливо його заповідні території, може 3 успіхом використовуватись в органічному виробництві. Застосування технологічних прийомів дозволяє виробляти ряд монофрлорних крафртових медів.

7. При розміщенні в лісі пасіки потрібно уберегтись від можливого збору бджолами нектару та пилку з отруйних рослин: чемериць, аконіту, рододендрону, богульника болотного, азалії понтійської, беладони, дурману.

\section{Список використаної літератури:}

1. Броварський В. Д. Методика дослідної справи у бджільництві. К. : Видавничий дім «Вініченко, 2017. 166 с.

2. Броварський В. Д., Папченко О. В. Кормові ресурси, розвиток і продуктивність бджолиних сімей. Вісник Житомирського національного агроекологічного університету. 2014. Вип. 23. № 2(44). С. 155-158.

3. Бурка А. Консультант ФАО [Електронний ресурс]. Режим доступу: https://ua-news.liga.net/ (дата звернення 21.03.2021).

4. Вербельчук С. П. Медовий запас та характеристика медозбірних угідь пасіки ЖНАЕУ в Овруцькому районі. Вісник ЖHAEУ. 2016. №1 (55), т. 3. С. 149-157.

5. Вербельчук Т. В., П'ясківський В. П. Роль лісу в підготовці сімей до бджолозапилення. Ефективне бджолозапилення: від підвищення урожайності до збереження біорізноманіття: матеріали наук.-практ. конф. з міжн. участю, м. Київ, 10 лист. 2020 р. Київ :USAID (АГРО), 2020. С. 29-30.

6. Вороненко О. Про антибіотики й пробіотики. Пасічник. 2021. Вип. № 1. С. 8-9.

7. Горніч М. Неонікотиноїди впливають на розвиток бджолиних сімей - нові дослідження. Пасіка. 2020. Вип. № 9. С. $14-15$. C. $14-17$

8. Держанський В. Проблеми колапсу бджолиних сімей і заходи для його попередження. Пасічник. 2020. Вип. № 11.

9. Дружбяк А. Й., Кирилів Я. І. Сезонні особливості білкового харчування медоносних бджіл. Науковий вісник ЛНУВМ імені С. З. Гжицького. 2010. Т. 12, № 3(3). С. 43-47.

10. Карван Д. Імунітет медоносної бджоли. Бджоляр. 2021. № 1. С. 17-19.

11. Коцюмбас О. Мікрофрлора пасік. Бджоляр. 2020. № 1. С. $26-27$.

12. Лебедев В. И., Билаш Н. Г. Биология медоносной пчелы. М. : Агропромиздат, 1991. 239 с.

13. Окуневський В. Збирання обніжжя: деякі застереження. Пасічник. 2020. № 8. С. 14-16.

14. П'ясківський В. М., Вербельчук Т. В., Вербельчук С. П. Джерела падевих медів Полісся. Інноваційні технології та інтенсифікація розвитку національного виробництва: матер. III міжнар. наук.практ. конф., м. Тернопіль, 20-21 жовтня 2016 р. Тернопіль : Крок, Ч. 1. 2016. С. 97-100.

15. П'ясківський В. М., Вербельчук С. П., Вербельчук Т. В. Остерігаємося дії на бджіл важких металів та їх солей. Пасічник. 2020. №10 (199). С. 14-15.

16. П'ясківський В. М., Вербельчук Т. В., Вербельчук С. П. Ширше використання бджолами лісового медозбору як альтернатива загрозам ГМО. Інтеграційна система освіти, науки і виробництва в сучасному інформаційному просторі: матеріали V міжнар. наук.-практ. конф., м. Тернопіль, 24 жовтня 2019 р. Тернопіль : Крок. С. 77-79.

17. Поліський природний заповідник [Електронний ресурс]. Режим доступу: http://tic.zt.ua/shchopodyvytys/pryrodookhoronni-obiekty/ovrutskyi-raion-pryrodookhoronni/133-poliskyi-pryrodnyi-zapovidnyk-2 (дата звернення 21.03.2021).

18. Поліщук В. П. Бджільництво. Львів: Редакція журналу «Український пасічник». 2001. 296 с.

19. Пономарев А. Меры по защите пчел и других опылителей рассмотрены в ООН. Бджолярський круг. За рентабельну пасіку. 2017. Вип. № 1. С. 48-50.

20. Сілі Т. Еволюційний підхід до апікультури (10 пропозицій для кращого утримання бджіл). Пасіка. 2020. Вип. № 1. 
C. $18-20$.

21. Словарь-справочник по пчеловодству / под. ред. А. И. Черкасовой. К. : Урожай, 1991. 415 с.

22. Таранов Г. Ф. Корма и кормление пчел. М. : Россельхозиздат, 1986. 160 с. 1987. $46 \mathrm{c}$

23. Таранов Г. Ф. Промышленная технология получения и переработки продуктов пчеловодства. М. : Агропромиздат,

24. Темнов В. А. Технология продуктов пчеловодства. М. : Колос, 1967. С. 67-182.

25. У Житомирській області порахували збитки від лісових пожеж [Електронний ресурс]. Режим доступу: https://www.slovoidilo.ua/2020/07/10/novyna/suspilstvo/zhytomyrskij-oblasti-poraxuvaly-zbytky-lisovyx-pozhezh (дата звернення 21.03.2021).

26. Хлебо Р. Запилення сільськогосподарських культур та скорочення запилювачів у Європі. Пасічник. 2020. Вип. № 7. C. $5-9$.

27. Чудаков В. Т. Технология продуктов пчеловодства. М. : Колос, 1979. 160 с.

28. Ян Наркевич-Йодко. Впровадження ГМО - загроза для бджіл. Український пасічник. 2017. Вип. № 12. С. $28-30$.

29. Askew Katy. Медозбір в Європі. Пасічник. 2021. Вип. № 1. С. 10-11.

30. Beebread. Resources and technologies production monograph. К. : НУБІП України, 2018. 149 c.

31. Brindza J. Biodiversity in the light of current, forgotten andforbidden sciences. Agrobiodiversity for Improve the Nutrition, Health and Quality of Human and Bees Life: book of Abstracts of the 4th International Scientific Conference (Nitra, Slovakia, 11th13th September 2019.). Nitra, Slovakia, 2019. Pp. 18-19.

32. Brindza J., Brovarskyi. V. Pollen and bee pollen of some plant species. Kyiv : Korsunskiy vidavnichiy dim Vsesvit, 2013.

33. Brovarskij V., Brindza J. Včelí obnôžkový pel'. Kyjev-Nitra: FOP I. S. Maidachenko, 2010. 290 p.

34. Brovarskiy V., Brindza J, Tkachenko O. Ethology ofbees by using different constructions of hanging pollen collectors. Agrobiodiversity for Improve the Nutrition, Health and Quality of Human and Bees Life :book of Abstracts of the 4th International Scientific Conference (c. Nitra, Slovakia, 11th-13th September 2019). Nitra, Slovakia, 2019. Pp. 22-23.

35. Leita L. Investigation of the use of honey bee products. Allg. Dt. Imcer. 2003. Vol. 17. P. 231-243.

36. Nation L. L. Concentration of some major and trace elements in honey bees. S. Apicult. Res. 1997. № 10. P. 33-34.

\section{References:}

1. Brovarskyi, V.D., 2017. Metodyka doslidnoi spravy u bdzhilnytstvi [Research methods in beekeeping]. Kyiv: Vydavnychyi dim «Vinichenko. 166 p.

2. Brovarskyi, V. D., Papchenko, O. V., 2014. Kormovi resursy, rozvytok i produktyvnist bdzholynykh simei [Feed resources, development and productivity of bee colonies.]. Visnyk Zhytomyrskoho natsionalnoho ahroekolohichnoho universytetu [Zhytomyr National Agrarian and Ecological University Journal], issue 23. № 2(44), pp. 155-158.

3. Burka, A., 2021. Konsultant FAO [FAO Consultant] [Elektronnyi resurs]. Rezhym dostupu: https://ua-news.liga.net/ (data zvernennia 21.03.2021).

4. Verbelchuk, S. P., 2016. Medovyi zapas ta kharakterystyka medozbirnykh uhid pasiky ZhNAEU v Ovrutskomu raioni [Honey stock and characteristics of honey-gathering lands of ZhNAEU apiary in Ovruch district]. Visnyk Zhytomyrskoho natsionalnoho ahroekolohichnoho universytetu [Zhytomyr National Agrarian and Ecological University Journal], issue 1 (55), t. 3, pp. 149-157.

5. Verbelchuk, T. V., Piaskivskyi, V.P., 2020. Rol lisu v pidhotovtsi simei do bdzholozapylennia. Efektyvne bdzholozapylennia: vid pidvyshchennia urozhainosti do zberezhennia bioriznomanittia [The role of forests in preparing families for bee pollination. Effective bee pollination: from increasing yields to preserving biodiversity] : materials of the scientific-practical conf. with international participation, Kyiv, 10 November 2020 r. Kyiv, pp. 29-30. pp. 8-9.

6. Voronenko, O., 2021. Pro antybiotyky y probiotyky [About antibiotics and probiotics]. Pasichnyk [Beekeeper], issue 1,

7. Hornich, M., 2020. Neonikotynoidy vplyvaiut na rozvytok bdzholynykh simei - novi doslidzhennia [Neonicotinoids affect the development of bee colonies - new research.]. Pasika [Apiary], issue № 9, pp. 14-15.

8. Derzhanskyi, V., 2020. Problemy kolapsu bdzholynykh simei i zakhody dlia yoho poperedzhennia [Problems of collapse of bee colonies and measures to prevent it]. Pasichnyk [Beekeeper], issue № 11, pp. 14-17.

9. Druzhbiak, A. Y., Kyryliv, Ya. I., 2010. Sezonni osoblyvosti bilkovoho kharchuvannia medonosnykh bdzhil [Seasonal peculiarities of protein nutrition of melliferous bees]. Naukovyi visnyk LNUVM imeni S. Z. Gzhytskoho [Scientific messenger of Lviv National University of Veterinary Medicine and Biotechnologies named after S. Z. Gzhytskyi], issue 12, № 3(3), pp. $43-47$.

10. Karvan, D., 2021. Imunitet medonosnoi bdzholy [Honey bee immunity]. Bdzholiar [Beekeeper], issue 1, pp. 17-19.

11. Kotsiumbas, O., 2020. Mikroflora pasik [The microflora of the apiary]. Bdzholiar [Beekeeper], issue 1, pp. $26-27$.

12. Lebedev, V. Y., Bylash, N. H., 1991. Byolohyia medonosnoi pchely [Honey bee Biology]. M. : Ahropromyzdat. 239 p.

13. Okunevskyi, V., 2020. Zbyrannia obnizhzhia: deiaki zasterezhennia [Picking up gare: some caveats]. Pasichnyk [Beekeeper], issue 8, pp. 14-16.

14. Piaskivskyi, V. M., Verbelchuk T. V., Verbelchuk S. P., 2016. Dzherela padevykh mediv Polissia. Innovatsiini tekhnolohii ta intensyfikatsiia rozvytku natsionalnoho vyrobnytstva [ Sources of Polissia honey. Innovative technologies and intensification of development] : materials of the III scientific-practical conf., Ternopil, October 20-21 2016. Ternopil, pp. 97-100.

15. Piaskivskyi, V. M., Verbelchuk, S. P., Verbelchuk, T. V., 2020. Osterihaiemosia dii na bdzhil vazhkykh metaliv ta yikh 
solei [Beware of the effects of heavy metals and their salts on bees]. Pasichnyk [Beekeeper], issue 10 (199), pp. 14-15.

16. Piaskivskyi, V. M., Verbelchuk, T. V., Verbelchuk, S. P., 2019. Shyrshe vykorystannia bdzholamy lisovoho medozboru yak alternatyva zahrozam HMO. Intehratsina systema osvity, nauky i vyrobnytstva v suchasnomu informatsiinomu prostori [Wider use of forest honey by bees as an alternative to GMO threats. Integration system of education, science and production in the modern information space] : materials of the V International scientific-practical conf., Ternopil, 24 October, 2019. Ternopil, pp. 77-79.

17. Poliskyi pryrodnyi zapovidnyk [Polissya Nature Reserve] [Elektronnyi resurs]. Rezhym dostupu: http://tic.zt.ua/shchopodyvytys/pryrodookhoronni-obiekty/ovrutskyi-raion-pryrodookhoronni/133-poliskyi-pryrodnyi-zapovidnyk-2 (Accessed 21.03.2021).

18. Polishchuk, V. P., 2001. Bdzhilnytstvo [Beekeeping]. Lviv: Redaktsiia zhurnalu «Ukrainskyi pasichnyk». 296 p.

19. Ponomarev, A., 2017. Mery po zashhite pchel i drugih opylitelej rassmotreny v OON [Measures to protect bees and other pollinators are being considered by the UN]. Bdzholiarskyi kruh. Za rentabelnu pasiku [Beekeeping circle. For a profitable apiary], issue 1, pp. 48-50.

20. Sili, T., 2020. Evoliutsiinyi pidkhid do apikultury (10 propozytsii dlia krashchoho utrymannia bdzhil) [An evolutionary approach to apiculture (10 suggestions for better beekeeping)]. Pasika [Apiary], issue № 1, pp. 18-20.

21. Slovar'-spravochnik po pchelovodstvu [Apiculture Dictionary] / pod. red. A. Y. Cherkasovoi. K. : Urozhai, 1991. 415 p.

22. Taranov, H. F., 1986. Korma i kormlenie pchel [Food and feeding of bees ]. M. : Rosselkhozyzdat. $160 \mathrm{p}$.

23. Taranov, H. F., 1987. Promyshlennaia tekhnolohyia poluchenyia y pererabotky produktov pchelovodstva [Industrial technology for the production and processing of beekeeping products]. M. : Ahropromyzdat, $46 \mathrm{~s}$.

24. Temnov, V. A., 1967. Tekhnolohyia produktov pchelovodstva [Beekeeping product technology]. M. : Kolos, pp. 67-182.

25. U Zhytomyrskii oblasti porakhuvaly zbytky vid lisovykh pozhezh [In the Zhytomyr region, losses from forest fires were calculated] [Elektronnyi resurs]. URL: https://www.slovoidilo.ua/2020/07/10/novyna/suspilstvo/zhytomyrskij-oblasti-poraxuvalyzbytky-lisovyx-pozhezh (Accessed 21.03.2021).

26. Khlebo, R., 2020. Zapylennia silskohospodarskykh kultur ta skorochennia zapyliuvachiv u Yevropi [Pollination of crops and reduction of records in Europe]. Pasichnyk [Beekeeper], issue № 7, pp. 5-9.

27. Chudakov, V. T., 1979. Tekhnolohyia produktov pchelovodstva [Technology of beekeeping products]. M. : Kolos. $160 \mathrm{p}$.

28. lan, Narkevych-Yodko, 2017. Vprovadzhennia HMO - zahroza dlia bdzhil [The introduction of GMO is a threat to bees]. Ukrainskyi pasichnyk [Ukrainian beekeeper], issue 12, pp. 28-30.

29. Askew, Katy, 2021. Medozbir v Yevropi [Honey gathering in Europe]. Pasichnyk [Beekeeper], issue 1. Pp. 10-11.

30. Beebread. Resources and technologies production monograph. 2018. K. : NUBIP Ukrainy, 149 p.

31. Brindza, J., 2019. Biodiversity in the light of current, forgotten andforbidden sciences. Agrobiodiversity for Improve the Nutrition, Health and Quality of Human and Bees Life :book of Abstracts of the 4th International Scientific Conference (Nitra, Slovakia, 11th-13th September 2019.). Nitra, Slovakia, Pp. 18-19.

32. Brindza, J., Brovarskyi., V., 2013. Pollen and bee pollen of some plant species. Kyiv : Korsunskiy vidavnichiy dim Vsesvit, Pp. 7-15.

33. Brovarskij, V., Brindza, J., 2010. Včelí obnôžkový pel'. Kyjev-Nitra : FOP I. S. Maidachenko, 290 p.

34. Brovarskiy, V., Brindza, J, Tkachenko, O., 2019. Ethology ofbees by using different constructions of hanging pollen collectors. Agrobiodiversity for Improve the Nutrition, Health and Quality of Human and Bees Life :book of Abstracts of the 4th International Scientific Conference (s. Nitra, Slovakia, 11th-13th September 2019). Nitra, Slovakia, Pp. 22-23.

35. Leita, L., 2003. Investigation of the use of honey bee products. Allg. Dt. Imcer. Vol. 17. Pp. 231-243.

36. Nation, L. L., 1997. Concentration of some major and trace elements in honey bees. S. Apicult. Res. № 10. Pp. 33-34.

Verbelchuk Tetiana Vasylivna, Candidate of Agricultural Sciences, Associate Professor, Polissia National University Pyaskivskiy Volodymyr Martsinovich, Candidate of Agricultural Sciences, Associate Professor, Polissia National University

Verbelchuk Serhii Petrovych, Candidate of Agricultural Sciences, Associate Professor, Polissia National University

Havrylovskyi Volodymyr Petrovych, Lecturer, Vice-principal for Education and Production, Zhytomyr Agrotechnical College (Zhytomyr, Ukraine)

Rationalizality for the use of forest harvesting in the formation of bees immunity

The evolutionary development of bees took place on a rich polyfloral forage base. The honey bee belongs to insects with narrowly specialized food. The whole complex of nutrients necessary for the development and nutrition of offspring and adults is obtained from nectar and pollen, which bees, for long-term storage, canned in honey and perga. The nutritional value of pollen is determined by its protein content, the completeness of the amino acid composition, the ability to assimilate. The selectivity of pollen collection is partly explained by the need of bees for this period in certain substances. In addition, it was found that the pollen of different pollinators differs in its biological value, pollen productivity, chemical composition. It is proved that one of the reasons for the decrease in the immunity of bees is the deterioration of their nutrition. This is due to the reduction of biodiversity of flowering plants near fields, monoculture agriculture, high pesticide background, climate change and so on. Therefore, polyfloral, full-fledged pollennectar feed base plays a fundamental role for the life and development of bees. Complete feeding of larvae lays the foundation for immune stability, health, and life expectancy for the rest of the insects' lives. This is too important for the reproduction of future queens, drones. It is known that the larval stage is the formation of the so-called fat body, which is a depot of proteins and other $B A S$, and then serves as a basis for the formation of secretory activity (royal jelly, enzymes for nectar processing, wax secretion, etc.). The formation of the fat body takes place during the larval stage of brood development. It ensures the long life of wintering bees, the ability to survive and survive the cold, contributes to the crucial task of these bees - feeding one replacement bee and more. Summer short-lived bees feed up to four individuals. As in higher animals and humans, the microflora of the mucous mem- 
branes and intestines plays an important role in maintaining immunity. It partially provides enzymatic processes in digestion. Due to these saprophytic microorganisms - immunity is formed (up to $80 \%$ ). The forest is able to provide bees with early polyfloral flowering plants, which will improve the quality of protein nutrition, promote high viability of offspring and actively increase family strength, future productivity, winter hardiness, ensure the efficiency of the industry.

Key words: bee, monoculture agriculture, food stresses of bees, building family strength, forest honeybees, immunity.

Дата надходження до редакції: 18.03.2021 р. 